\title{
Roundtable
}

\section{English Nationalism and Euroscepticism: A discussion}

British Politics (2016) 11, 347. doi:10.1057/bp.2015.5; advance online publication 20 June 2016

\section{Introduction}

In this roundtable discussion, Michael Kenny, Chris Gifford and Emma Vines engage with the central thesis of Ben Wellings' English Nationalism and Euroscepticism that resistance to European integration has shaped the content of contemporary English nationalism. Michael Kenny focuses on the origins and drivers of English nationalism, arguing that the focus on Euroscepticism is too narrowly drawn and that a focus on nationalism rather than nationhood hides as much as it reveals. Chris Gifford analyses the relationship between populism, nationalism and Euroscepticism, arguing that populism and party de-alignment rather than nationalism has more explanatory force in accounting for Euroscepticism in Britain, all of which represents the end of Anglo-Britishness rather than the rise of Englishness. Emma Vines concentrates on the consequences of English nationalism to date for the British Political Tradition and argues that such nationalism has been co-opted by the traditional parties. Lastly, Ben Wellings responds to this engagement and re-states a case for viewing Euroscepticism as the most formed-up expression of contemporary English nationalism. 